RESEARCH PAPER

\title{
"If we can just 'stall' new unfriendly legislations, the scoreboard is already in our favour": transnational tobacco companies and ingredients disclosure in Thailand
}

\author{
R MacKenzie, J Collin, K Sriwongcharoen, M E Muggli
}

Tobacco Control 2004;13(Suppl II):ii79-ii87. doi: 10.1136/tc.2004.009233

See end of article for authors' affiliations

Correspondence to: Mr Ross MacKenzie, Centre on Global Change and Health, London School of Hygiene and Tropical Medicine, Keppel Street, London WCl 7HT, UK; ross.mackenzie@ Ishtm.ac.uk

\begin{abstract}
Objectives: To review the strategies employed by overseas cigarefte manufacturers operating in Thailand to obstruct the passage and subsequent enforcement of national public health legislation, specifically the ingredients disclosure provision of the 1992 Tobacco Products Control Act.

Methods: Analysis of previously confidential tobacco industry documents relevant to non-compliance with the ingredients disclosure legislation.

Results: Requirement for disclosure of ingredients contained in cigarettes contained in the Tobacco Products Control Act was identified by transnational tobacco companies (TTCs) not only as a significant threat to their operations in Thailand, but as a dangerous global precedent. Industry documents reveal a determined campaign to block, stall, or amend the proposed regulation during the legislative process. Industry representatives petitioned the Ministry of Health to revise the requirement from by brand disclosure to a more palatable by company submission. Strategies were adapted in the wake of the passage of the Act. Most significantly, the industry in concert with embassies in Bangkok threatened the Thai government with appeals to international trade bodies on the grounds of violation of international agreements. Industry documents also reveal that as submission of ingredient lists appeared unavoidable, leading companies operating in Thailand endeavoured to confound the disclosure requirement by disguising ingredients and reformulating brand recipes.

Conclusions: The evidence presented highlights the importance of ingredients regulation and demonstrates how health policy can be transformed during its implementation. A greater understanding of trade agreements emerges as a priority for global tobacco control.
\end{abstract}

$T$ hailand's 1992 enactment of comprehensive tobacco control legislation represents a landmark in global health regulation..$^{1-4}$ The dual passage of the Tobacco Products Control Act (TPCA) and the Non-Smokers Health Protection Act occurred in an extraordinary political context. Targeted by transnational tobacco companies (TTCs), and resisting the threat of retaliatory trade sanctions by the USA, arbitration under the General Agreement on Tariffs and Trade (GATT) required the opening to imports of Thailand's previously closed tobacco market. ${ }^{5-8}$ A distinctively national response to corporate and international pressure, ${ }^{9}$ Thailand's legislation has since proved remarkably successful in curbing the rise in tobacco consumption despite the challenges posed by trade liberalisation. ${ }^{10}$

Yet this success has not been unequivocal. Provisions for disclosure of cigarette ingredients ${ }^{11}$ have recently been dismissed by one of the Act's foremost advocates as "useless", 9 having been subjected to protracted delays and then fatally undermined. ${ }^{12}$ 12 The TPCA did not specify requirements for ingredients disclosure, rather requiring the subsequent development of a ministerial regulation. This regulation was not approved until 1995, with a further two year wait before it was signed into law. Ingredients information was finally supplied by TTCs to the Thai Ministry of Public Health in 1998, with the crucial qualification that it remain confidential.

This dilution has long been attributed to continuous pressure brought by TTCs, ${ }^{13}$ but the disclosure of corporate documents allows for a detailed exploration of the strategies by which Thailand's legislative intent was gradually displaced. While the significance of ingredients issues for public health have been considered elsewhere, ${ }^{14-18}$ this paper rather uses internal documents to provide a detailed examination of how TTCs influenced the policy process in Thailand. Having briefly illustrated the regional and global significance to the TTCs of ingredient disclosure in Thailand, the paper discusses their efforts to prevent its inclusion in legislation. It then focuses on how the TTCs successfully shaped policy during its prolonged implementation, highlighting the influence of foreign governments and international organisations.

\section{METHODS}

The general strengths and limitations of tobacco industry document research have been previously described, ${ }^{19-22}$ while the more specific difficulties of working with British American Tobacco (BAT) documents at depositories in Guildford, UK, and Minnesota, USA, have recently been highlighted. ${ }^{23-25}$

Additionally, documents available for this study are primarily correspondence between Thailand and regional offices and company headquarters. Records held by company offices in Bangkok and other regional centres have not been disclosed.

Abbreviations: AMGP, Additives and Materials Guidance Panel; BAT, British American Tobacco; B\&W, Brown \& Williamson; DTI, UK Department of Trade and Industry; EU, European Union; FCTC, Framework Convention on Tobacco Control; GAT, General Agreement on Tariffs and Trade; FDA, US Food and Drug Administration; IPR, intellectual property rights; $\mathrm{MOH}$, Thailand Ministry of Health; PM, Philip Morris; RJR, RJ Reynolds; TPCA, Tobacco Products Control Act; T\&N, tar and nicotine; TBT, technical barriers to trade; TRIPS, trade related aspects of intellectual property rights; $\Pi \mathrm{TC}$, transnational tobacco companies; WTO, World Trade Organization 
Document research for this paper was primarily carried out at BAT's Guildford depository following an iterative search strategy; initial use of broad terms such as "ingredients", "disclosure", "additives", "Thailand", and "legislation" led to more specific searches using names of company personnel, and Thai political and administrative figures. Evidence of cross industry collaboration led to similar searches of document collections of Philip Morris (PM) and RJ Reynolds (RJR) on company operated sites and the University of California, San Francisco (UCSF) Legacy and Tobacco Documents Online websites. The protracted nature of the dispute required the examination of BAT documents made available at the Minnesota depository through ongoing litigation..$^{23}$

Secondary research included examination of existing literature on cigarette ingredients and studies of Thailand's political system. Finally, interviews in Bangkok in September 2003 with Dr Hatai Chitanondh and Dr Prakit Vateesatokit have provided invaluable further information.

\section{RESULTS}

\section{TTCs and ingredients disclosure in Thailand}

Corporate documents indicate that all other aspects of Thailand's proposed comprehensive legislation were viewed as "less important compared with the ingredients issue". ${ }^{26}$ Tobacco companies have publicly explained the issue's importance in terms of the commercial sensitivity of proprietary information. In discussions with Thai officials the TTCs insisted that "cigarette ingredients are commercially valuable closely-guarded trade secrets of the manufacturers and must be maintained in the strictest confidence", ${ }^{27}$ framing the debate around a trade issue rather than health. In response to media exposure of "sheep dip and rat poison" in New Zealand cigarettes, BAT insisted:

We are not trying to hide the ingredients from smokers, and there is nothing underhand or sinister in the fact that the list was not publicly available. We aim simply to preserve commercial confidentiality of product formulae and recipies, as would for instance Coca Cola, which seeks to preserve the confidentiality of the recipe for its soft drinks. ${ }^{28}$

This "Coca Cola defence" ${ }^{14}$ reduces the threatening to the mundane, but offers at most a partial explanation for the concerns of TTCs. In 1994, for example, BAT placed retaining confidential information alongside objectives of preserving "the company's individual ability to satisfy consumer tastes" and preventing "ill-informed abuse of the company, its products and the tobacco industry". ${ }^{29}$ In New Zealand, this emphasis on avoiding embarrassment provided "[t]he only reason for wishing to keep the list that we actually submitted confidential". ${ }^{30}$ BAT's 1996 projections on future business similarly noted that "given the anti-smoking movement is aware that a brand-by-brand disclosure of ingredients would be threatening because of the competitive formula issue, they will continue to lobby for this very hard with governments" ${ }^{31}$

Inadequate knowledge and coordination also contributed to the scale of industry concerns. In 1994, BAT policy was that any enforced disclosure should be "restricted to additives to tobacco only", ${ }^{29}$ an approach that might explain an earlier acknowledgement that "we have made no attempt to check all the other materials apart from tobacco additives so far, which makes for a considerable degree of total vulnerability". ${ }^{32}$ BAT suffered from a fragmented approach to additive issues, particularly regarding brands owned by US subsidiary Brown \& Williamson (B\&W), noting that legislation in Thailand and New Zealand required a more concerted response. $^{33}$ Its Additives and Materials Guidance Panel (AMGP) was notably dissatisfied with the limited detail $\mathrm{B} \& \mathrm{~W}$ was willing to provide:

(T)he release of the US list to the AMGP would not satisfy our needs in that it is an aggregate industry list, it is retrospective and records total additives used by pound of tobacco processed in the US. The whole basis of risk evaluation and assessment for safe use of additives requires quantitative data by brand. ${ }^{34}$

Importantly, an internal dispute thus highlights the utter inadequacy of the approaches to ingredients disclosure publicly promoted by TTCs.

The commitment to resisting Thailand's ingredients legislation is arguably best explained by fears of a "domino effect" ${ }^{\prime 35}$ regionally ${ }^{36}$ and globally. ${ }^{37}$ In 1991 PM's FJ Moreno warned that the proposals "constitute a very dangerous precedent which could affect us in other markets as well as in Thailand itself". ${ }^{38}$ RJR's Don Foreman noted the industry's difficulty in containing the issue in other markets and warned that Thailand's legislation "could carry serious global repercussions", making it "important from an overall corporate viewpoint that we do everything possible to prevent it" ${ }^{\prime 39}$ While Thailand itself followed Canada's example, ${ }^{9}$ BAT's Andrew Leung argued that it would have much greater impact:

\section{It sets a real bad example for other Asia-Pacific markets to follow. Although Canada is the first one to require ingredient disclosure, Asia-Pacific markets usually regard Canada as a low profile developed Western country which is different from them. Thailand now comes up with a more stringent set of requirements, other Asia-Pacific markets will definitely look into the issue and they will be under pressure from anti-smoking activists to follow suit. This has a more detrimental impact on our business in (sic) long term. ${ }^{40}$}

\section{Lobbying to prevent the 1992 legislation}

The substantial collective lobbying effort undertaken to defeat the proposed legislation is generally regarded as having been unsuccessful. ${ }^{10}{ }^{13}$ Certainly it did not always go smoothly, and resulted in considerable embarrassment ${ }^{213}$ when PM's Paitoon Virochpoka "unfortunately got carried away with PM's lobbying efforts and attended a committee meeting posing as an assistant to Senator Dusit". ${ }^{41}$ This comic incident indicates the high level access acquired by TTCs within a system prohibiting lobbying while legislation is considered, ${ }^{26}{ }^{42}$ and TTCs were officially not privy to details of Section $11 .{ }^{43-45}$ The government issued media warnings to reinforce the ban on lobbying, a move described by Aitken as a "preemptive tactic to warn any of the industry's potential supporters that they are vulnerable to be finger pointed for accepting bribery" ${ }^{46}$ The TTCs undertook a covert campaign to undermine the prohibition on lobbying, with Harris noting that "monitoring and actions with respect to the Tobacco Control Bill have been necessarily difficult and non-public" ${ }^{47}$

Correspondence from February and March 1992 demonstrates that the ban did not preclude extensive contacts with politicians and officials. BAT's Viroj reportedly received information from a "friend in the FDA" [US Food and Drug Administration], ${ }^{48}$ while Harris planned for PM's lawyer to "meet with our contact at the FDA within the $\mathrm{MOH}$ [Ministry of Health] who is a possible candidate to be on the panel to draft the 'standards"'. ${ }^{26}$ Viroj reported that he and 
Paitoon met with Thammanoon Ladplee, a senior member the National Legislative Assembly, "to try to influence him to veto the Tobacco Control Bill on the ground [sic] of ambiguity of the law and the broad power of $\mathrm{MOH}$ [Ministry of Health]". ${ }^{49} 50$ In March, industry consultant Paul Dietrich ${ }^{51}$ described receiving information from his contact in the Ministry of Health, ${ }^{52}$ while BAT's David Aitken refers to lobbying senior senators in hopes "they will intervene on our behalf"..$^{53}{ }^{54}$

The TTCs forged their most important relationship with Meechai Rachuphan, Thailand's Deputy Prime Minister. Notes of his initial meeting with industry representatives in September 1991 cite the objective of establishing a dialogue with the government, "particularly to contribute our knowhow on the ingredients issue", ${ }^{55}$ and presented the proposed legislation as threatening an increase in smuggling (transit products)..$^{556}$

The industry found the outcome "much more positive than anticipated", prematurely concluding that the Bill's threat "is no longer serious". Meechai's opening remark was reportedly "that he disagreed with the Bill and that it was unnecessary"; he was receptive to suggestions that the ingredients proposals should be replaced following the "Singapore model" of banded declarations of tar-nicotine levels; and he advised the industry both to "express their concern to the Judicial Council" and to "start up some dialogue with the Minister of Health", mentioning that "he would give the Health Minister a call and sound him out". The industry representatives subsequently agreed not to inform their distributors of the meeting "to pre-empt any leakage to the press who could put the Deputy Premier and the Government on the defensive". ${ }^{55}$

The TTCs subsequently viewed Meechai as a key ally against ingredient disclosure, seeking "to equip the Deputy Prime Minister with ammunition to counter the Tobacco Control Bill before it reaches the cabinet" ${ }^{57}$ Hatai's account of the passage of the legislation notes both that in February 1992 the Deputy Prime Minister "requested that the article [on ingredients disclosure] be deleted" and that in March the bills had been "suspiciously moved to the last order on the agenda", ${ }^{13}$ thus jeopardising its passage before the House adjourned.

In March 1992, shortly before the legislation received final reading, British American Tobacco UK and Export's (BATUKE) Richard Davies informed B\&W's Gene Russell that "our staff have confirmed that lobbying the senior senators is on-going to have the section on ingredients removed and to have tar and nicotine substituted" ${ }^{\prime 58}$ Attempting to switch the government's attention to tar and nicotine $(\mathrm{T} \& \mathrm{~N})$ measurement became the preferred option of the TTCs, with a "ready made" list of ingredients viewed as a compromise position. ${ }^{59}$ Some were sceptical as to the chances of the T\&N approach being influential, ${ }^{60}$ with Don Harris of PM's Hong Kong office noting in October 1991 that "under the circumstances it seems increasingly unlikely". ${ }^{61}$

A list of ingredients by company was promoted as sufficiently rigorous to satisfy regulatory demands in Europe, suggesting that "there would be considerable financial savings and administrative efficiency if a government were to embrace these internationally recognised lists". ${ }^{27}$ Harris described PM's strategy as aiming "to have the public disclosure provision removed form the Bill, to have the issue dealt with as regulations rather than law" and to have the Thai government accept one of the lists used in Europe. ${ }^{47}$ The prospects for a composite list were dismissed by BAT's Terry Mitchell as "acceptable to no one of any consequence except with massive qualification," with its only potential as "a way of buying time". ${ }^{62}$

As pessimism grew about transforming the Bill, attention turned to efforts to delay its passage in the hope that the
March election might change the political climate. BAT's Aitken proposed to "influence the Cabinet to stall the Bill by setting up a scrutiny committee to review it"; this would involve advising "our sympathetic Deputy Prime Minster, Meechai Rachuphan, to be on the alert". ${ }^{63}$

The 1992 legislation has been depicted as passed "with no concessions given to the industry", ${ }^{1}$ yet documents indicate that the provisions for ingredients disclosure became more palatable to the TTCs during this period of intensive lobbying. ${ }^{26}$ BAT's Richard Davies noted in January 1992 that "the Clauses on ingredients have now been modified and are less controversial as far as we are concerned". ${ }^{64}$

Such caveats notwithstanding, the TPCA constituted a remarkable triumph for health campaigners. Section 11 compelled the submission of ingredients lists by cigarette manufacturers, provided for control of hazardous substances, and empowered the Minister of Health to specify the detailed requirements for submission. An explanation of why Thailand's ingredients provisions are now so disparaged needs to focus on the policy influence of TTCs after the legislative phase.

\section{TTC policy influence during implementation}

Both the requirement of a further ministerial regulation and the broader political context facilitated TTC influence. Thailand's political instability and frequent changes of government in the 1990s shaped the emergent saga of ingredients disclosure. The office of Minister of Public Health, for example, changed hands nine times between 1992 and $1998,{ }^{65}$ a rotation that greatly influenced the politics of ingredients disclosure. Pirote, health minister during the Act's passage and again from June to September 1992, was reluctant to meet with the TTCs and was a source of great frustration to them. ${ }^{66-68}$ By contrast, Boonphan Kaewattana, Pirote's successor as minister on both occasions, was far more amenable. ${ }^{69}$ Notes from a meeting with Boonphan in February 1993 highlight his "intention to help the industry because of his long relationship with" the father of RJR's distributor and, in reference to ingredients regulation, describe him asking the industry to "prepare the details of our preferred version so that he can ask the Ministry to submit him the right draft which he will show us before signing it to be proceeded for Cabinet approval". ${ }^{70}$

Documents detailing contacts with Boonphan also highlight the "heady mix of pluralism and structural corruption" characteristic of Thai politics during this period. BAT's Aitken alleged that Boonphan could be "assumed to have 'sticky fingers' as can deputy Health Minister Somsak Thepsuthin", ${ }^{71}$ while notes from the February 1993 meeting concluded "the only means of negotiation with politicians is dollar and cent". ${ }^{70}$ The minister who eventually signed the regulation in 1997, Montri, was later described as having been "at the centre of allegations/rumours that he wanted US $\$ 5$ million!"”.72

The industry seemingly achieved a breakthrough in August 1992 when Pirote unexpectedly agreed to disclosure of ingredients on a by company basis, additives by brand family, while $T \& N$ and carbon monoxide (CO) were to meet ISO standards ${ }^{73}$ (again, previously suggested by the indus$\left.\operatorname{try}^{69}\right)$. This compromise was predictably welcomed by Philip Morris International (PMI) ${ }^{74}$ and $\mathrm{RJR}^{75}$ but the ministry subsequently reverted to its prior position of by brand disclosure; neither the offer nor the withdrawal of the compromise has been satisfactorily explained.

The situation facing the TTCs was exacerbated by public disclosure of ingredient lists in New Zealand in 1994 under freedom of information legislation ${ }^{76}$ described by BAT's Rajiv Goel as "ammunition for Thai doctors on ingredients by 
brand". ${ }^{77}$ The Thai media then reported that the ministerial regulation was back on track, but PM's Patrick Rekart remained confident of prevailing on "the issue that refuses to die!" ${ }^{78}$ Rekart called for a clear negotiating line, suggesting "we need to establish just how far we would go in regard to a detailed list". ${ }^{78}$

TTCs continued to lobby the government 727980 "for amendment of the regulation to a more acceptable level"s1 throughout the dispute, but were increasingly turning their attention to how to respond in the event of their political failure. The dramatic alternative of withdrawal from the Thai market was rejected by $\mathrm{BAT}^{82}$ for whom in the event of a requirement for by brand disclosure "our 'bottom line' is that we will comply with government regulations to do so and so long as this is practical for us" ${ }^{83}$ Philip Morris had more seriously considered withdrawal, or at least to its threat, but William Webb advised CEO Geoffrey Bible against it "because of the loss of business and also because other countries would see the adoption of brand formula disclosure requirements as a way of driving Philip Morris from the market" ${ }^{84}$

PM's Don Harris later made oblique reference to the company having taken "the precaution to protect our primary products in the Thai market". ${ }^{85}$ One possible route towards such protection was reformulation of brands, in which PM seemingly took the initiative among the TTCs ${ }^{85}$ Webb advised Bible to ensure the confidentiality of their leading brand by modifying "the Thai Marlboro so that disclosure of its formula will not compromise the international Marlboro

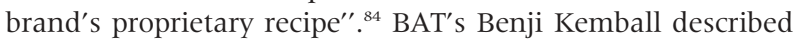
reformulation of brands as the only realistic option "particularly given the competition, especially PMI, will proceed with reformulated versions", ${ }^{\prime 6}$ and sought to convince B\&W of its merits. ${ }^{82}$ Andrew Leung argued in July 1995 that "[w]e need to quickly look into reconstituting products for Thailand domestic market", claiming that "PMI may have already reformulated Marlboro for this market". ${ }^{81}$ Minutes of a September 1995 meeting similarly note that "the introduction of 'spoiler' brands will be considered in order to mask sensitive information". ${ }^{87}$ Within four years, reformulation had reportedly been applied to 555, Lucky Strike, and Benson \& Hedges sold on the Thai market "obviously to avoid disclosing some ingredients" ${ }^{88}$

The TTCs also collaborated in producing a composite list for potential use in Thailand, to be prepared and retained by prominent industry law firm Covington and Burling in accordance with a confidentiality agreement. ${ }^{89}$ This agreement precluded, inter alia, "discussing the contents of the composite list with, or submission of the composite list to, Thailand government officials".$^{90}$

The documents suggest an interest in constructing lists so as to disguise ingredients or to deflect expected criticism. PM's William Webb informed Bible:

\section{...it would be our intention to first supply a general list of all ingredients used and then list as an item, for example, 'flavor package number manufacturer supplied by flavour In way, we may be able to continue to disguise the ingredients by brand and also the amount used. ${ }^{91}$}

Later email exchanges within BAT regarding how to comply with Thailand's eventual requirements suggest similar motivations, including references to a desire "to publish a list of only 30 natural sounding ingredients for Lucky Strike" ${ }^{\prime 92}$ and to include "'less controversial' ingredients" since some "appear to be more objectionable to the anti-smoking propagandists than others". ${ }^{93}$
One 1995 BAT document also indicates an intent to ensure supplies of smuggled cigarettes as a means of responding to the expected regulation. In an email copied to high ranking executives, Andrew Leung discussed preliminary preparations for the rapid supply of "GT stocks", an apparent reference to General Trade, a company euphemism for contraband:

We need to be ready to pump in GT stocks in case the supply is disrupted by the Regulation. I have checked with Hon Tay who does not see difficulty in providing urgent stocks for Thailand. ${ }^{40}$ (original emphasis)

\section{International pressure and ingredients disclosure in Thailand}

TTCs have consistently been able to invoke the support of powerful external actors in their efforts to undermine Thailand's legislation. Most prominently, this has been evident in the activities of the embassies and trade representatives of their sympathetic home governments in the USA, the UK, and Japan. ${ }^{94} 95$ These governments displayed an active interest in Thailand's provisions for ingredients disclosure from 1992 onwards, with embassies advancing arguments on behalf of "our tobacco industries". ${ }^{96}$ The ability of the TTCs to convince foreign governments that "ingredients should not be treated as a trade issue rather than a health issue ${ }^{\prime \prime 97}$ has been critical to their success in bringing international pressure to bear. The rationale for such interventions was increasingly based on arguments that disclosure provisions conflicted with Thailand's obligations under GATT and its successor the World Trade Organization (WTO). Such arguments assumed a particular weight for Thailand given both the enforced opening of its tobacco market to competition and a similar 1991 dispute over pharmaceutical patent regulation. ${ }^{98}$ A reluctance to revisit disputes between trade liberalisation and health policy has been seen as a major factor in the gradual weakening of disclosure requirements (Interview, Dr Prakit Vateesatokit, 17 September 2003).

Concerted efforts to exert international pressure on ingredients disclosure quickly followed the Act's passage in March 1992. During the legislative process PM had been keeping the USTR informed, but recognised that they could not "bring the USTR or Embassies into play until the bill is passed". ${ }^{99}$ By early April BAT's Richard Davies had arranged a meeting to brief the UK's Department of Trade and Industry (DTI) and requested an appointment at the British Embassy in Bangkok. ${ }^{100}{ }^{101}$ During a meeting with PMI, RJR, and B\&W in June 1992, USTR's Sandy Adams reportedly offered to "voice the industry's concern on the sensitivity of trade secret (sic) surrounding the full disclosure of ingredients". ${ }^{102}$ In September 1993 US Ambassador to Thailand David Lambertson sent a letter to Boonphan, then Minister of Public Health, urging the abandonment of any requirement for disclosure by brand. Advancing the industry's favoured alternative of disclosure "on a composite company-wide basis", Lambertson noted that the "United States Government does not oppose adoption of ingredient disclosure requirements meeting your government's public health objectives" but claimed that such an alternative could "address public health concerns without needlessly compromising individual brand formulas". ${ }^{103}$

The emphasis on diplomatic support in Thailand was heightened in 1994 following the embarrassment accompanying disclosure of ingredients from New Zealand, ${ }^{104}{ }^{105}$ with BAT's Rajiv Goel industry members to contact their embassies so that "if the MOPH [Ministry of Public Health] did 
come out into the open on the ingredients issue it would not be a 'shock"'. ${ }^{106}$ Rumours of an imminent ministerial regulation in March 1995 heightened the urgency of the issue ${ }^{107}$ triggering a new round of discussions with embassy officials. ${ }^{108}{ }^{109}$ In April a joint letter from the economic officers of the British, Japanese, and US Embassies bemoaned the Ministry of Public Health's unwillingness to consult with their respective tobacco industries and requested a meeting to present "our official and their commercial points of view on this issue before the Cabinet acts" ${ }^{\prime 96}$

The formation of the WTO in January 1995 led to renewed interest among TTCs in using trade agreements to exert pressure on Thailand. A joint letter to Deputy Prime Minister Meechai in early 1992 had claimed that "implementation of overly stringent regulations may result in non-tariff barriers being placed in the path of imported cigarettes".${ }^{110}$ Given the prevailing political context, this letter could reasonably have been interpreted as a veiled threat of another challenge to Thailand under GATT. Amid industry disagreement about the

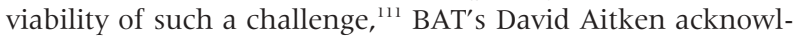
edged that "it would not be against GATT for the Thais to require complete disclosure of ingredients coupled with a ban on unhealthy substances", ${ }^{48}$ highlighting a specific endorsement of this prospect by GATT's arbitration panel. ${ }^{6}$ The industry was, however, quick to spot the greater political potential of invoking the WTO, particularly under the agreements on trade related aspects of intellectual property rights (TRIPS) and technical barriers to trade (TBT). In the UK, BAT quickly sought to engage the DTI, ${ }^{112}$ insisting that "Article 11 violates international trading agreements, as well as setting ingredients disclosure precedents that could eventually impact on many other industries". ${ }^{113}$ Correspondence with the British Embassy in Bangkok similarly cited trade violations, ${ }^{114}$ reportedly resulting in the deputy Head of Mission agreeing "to take the matter up with the relevant government department". ${ }^{115}$

Shortly after the May 1995 approval of the ministerial regulation on ingredients disclosure, a letter from BAT chairman Barry Bramley to Prime Minister Chuan Leekpai insisted that "the requirement of ingredients disclosure "by brand' is against the principle of intellectual property protection". ${ }^{116}$ An accompanying critical analysis of the ministerial regulations claimed the requirement "violates Thailand's obligations" under TRIPS and warned that "the regulations if gazetted could be subject to challenge before the World Trade Organization" ${ }^{117}$ The shared objective of the TTCs at this time was, in conjunction with a letter from the US, Japanese, and British Embassies, "to call the Prime Minister to delay the process so as for us to 'present' our case $^{\prime \prime} .{ }^{118}$

The claimed incompatibility of ingredients provisions with TRIPS was used to advance the TTCs preferred alternative of an industry wide or company level list. Minutes of an industry meeting in September 1995 describe a prior encounter between BAT and Minister of Public Health Sanoh Thienthong in which Martin Riordan presented such a list as avoiding the alleged IPR (intellectual property rights) implications of by-brand disclosure:

Riordan informed that Snoh was "very interested" in the IPR issue. At this point, Snoh called his Deputy Minister to find out about IPR implications and was told there were no IPR problems. Snoh mentioned (to BAT) that "more steel on IPR were needed" - referring to argumentation that the regulation would run afoul with the IPR. ${ }^{119}$

The threat of TRIPS emerges as something of a phantom used to intimidate Thai officials. Philip Morris told this industry meeting that "we have a weak IPR case", given improvements in Thailand's patent law, while the TTCs do not seem to have had a satisfactory response to the MOPH's frequent citation of the Canadian example: "How do we explain this? Why wasn't Canada challenged?" 119 PM's Don Harris similarly acknowledged that " $[\mathrm{t}]$ here is no IPR issue", ${ }^{85}$ yet comparable arguments continued to be advanced in using the TTM's 1997 launch of the 'Marble' brand, ${ }^{120}$ a Marlboro-style cigarette, as "a useful lobby"72 illustrating the alleged dangers of by-brand disclosure.

PM viewed the TBT agreement as providing a more promising basis for challenging the implementation of ingredients disclosure. ${ }^{119}$ Unofficial information from the European Union (EU) as well as the US and UK governments advised that "the proposed Regulation appears to constitute an actionable TBT", ${ }^{121}$ while USTR's Suzanne Troje reportedly felt that "there 'might be something' to our TBT argument". ${ }^{97}$ A complaint under the WTO's TBT agreement came to be identified as perhaps "the industry's best avenue for defeating the Regulation". ${ }^{121}$

The international dimension to TTC efforts continued beyond the final gazetting of the ingredients regulation in August 1997. This represented a major triumph for the TTCs in the abandonment of the requirement for public disclosure of ingredients. Nonetheless, lobbying activities continued to attempt to remove the requirement that information be supplied to the $\mathrm{MOH}$ on a by-brand basis. TTCs seemingly secured support in these efforts among Thailand's economic ministries, most notably from Dr Supachai Panitchapakdi, then Deputy Prime Minister and Minister of Commerce and currently the Director-General of the WTO. Dr Supachai reportedly secured a two week suspension of the regulation in February 1988 following a meeting with the industry. ${ }^{122}$ While seemingly becoming resigned to the regulation retaining its focus on brands, BAT's Martin Riordan suggested that Dr Supachai could advance minor amendments that would be strategically useful internationally:

\section{FYI, feedback today from the Economic Ministries of the Thai Government, and the US Embassy, were that we must keep some momentum up till the Deputy PM, and Minister of Commerce, Dr Supachai, can take any minor amend- ments we can suggest for 'by brand', but perhaps allowing disclosure by banding, or max levels, etc. This would help us internationally against unacceptable benchmarking of the Thai legislation. ${ }^{72}$}

BAT eventually complied with the regulation in 1998 only after receiving "assurances from the Thai authorities to us, the US Embassy and the European Commission office in Bangkok, about preserving confidentiality and keeping the disclosures secure in a locked safe with control of access" ${ }^{\prime 2}{ }^{123}$

\section{DISCUSSION}

A joint submission by Thai health agencies to the Cabinet's discussion of ingredients disclosure in May 1996 noted that "though the cigarette companies may be powerful in the U.S.A., they should not be allowed to exercise their power to dictate the details of Thai domestic laws" ${ }^{124}$ The remarkable achievements of health advocates in Thailand, since augmented by a health promotion institute funded by a share of revenue from tobacco and alcohol sales, ${ }^{9}$ clearly demonstrate that TTCs were unable to dictate its tobacco control policy. Yet even in Thailand the political influence of the TTCs has been both persistent and pervasive. Indeed on ingredients disclosure, the aspect of greatest importance to them, the TTCs transformed apparent defeat during the legislative 
Ingredients disclosure in Thailand: timeline of

key events

- 1989: National Committee for the Control of Tobacco Use (NCCTU) established, discussions begin on drafting tobacco product control legislation

- October 1990: Cabinet approval in principle for draft of Tobacco Products Control Act (TPCA)

- November 1990: General Agreement on Tariffs and Trade (GATT) panel rules that Thailand must open cigarette market to foreign manufacturers but acknowledges right implement tobacco control legislation provided it is applied equally to domestic and foreign producers.

- March 1992: TPCA passed by National Legislative Assembly. Section 11 authorised the Minister of Health to present a ministerial regulation on ingredient disclosure.

- August 1992: Government offers by company brands disclosure compromise, an offer subsequently withdrawn

- March 1994: Ingredient lists made public under freedom of information legislation in New Zealand

- January 1995: World Trade Organization inaugurated

- May 1995: Ministerial regulation approved in principle by Cabinet after lengthy delays

- August 1997: Ministerial regulation signed into law without requirement for public disclosure

- February 1998: Producers eventually comply with Thai legislation for by-brand ingredient lists after receiving strict assurances of confidentiality

process into a victory during protracted implementation. In May 1998 PM noted that compliance with the eventually gazetted regulation had been achieved "with minimal commercial disruption". ${ }^{125}$

Insights from the documents presented above raise a number of key issues of local and global relevance for tobacco control. The scale and intensity of efforts devoted to undermining Thailand's legislation for public disclosure of ingredients serves as a guide to the significance of this issue. The internal acknowledgement that the "whole basis of risk evaluation and assessment for safe use of additives requires quantitative data by brand" ${ }^{\prime 34}$ indicates the vacuity of voluntary disclosures under corporate social responsibility programmes. ${ }^{126}{ }^{127}$ More seriously, it also highlights the inadequacy of much existing legislation in this area. This concern is exacerbated by indications of a willingness to manipulate ingredients lists to minimise embarrassment and by the apparent reformulation of international brands to bypass disclosure requirements.

Most broadly, this case study illustrates that the policy process does not end with the passage of legislation, highlighting the critical significance of "post-policy-making". ${ }^{128}$ In many cases there remain substantial opportunities to transform the design and impact of legislation during its implementation, and TTCs are particularly well placed to exert influence here once public debate has subsided. The resource disparity between health agencies and TTCs can therefore make it extremely difficult to ensure that legislative intent is not distorted. In a global context, this broad concern illustrates the scale of the challenge confronting regulators in ensuring effective implementation of the World Health

\section{What this paper adds}

Thailand's 1992 Tobacco Products Control Act is justifiably cited as an example of effective tobacco control legislation and particular attention has been paid to its marketing restrictions.

The ingredients disclosure provision of the Act has proven less successful and previous studies have noted challenges by the tobacco industry to the regulation. This paper describes the strategies and tactics employed by tobacco companies operating in Thailand to undermine the regulation and the considerable success of their efforts.

Organization's Framework Convention on Tobacco Control (FCTC). ${ }^{129130}$

The support given to "our tobacco industries" ${ }^{\prime 96}$ by wealthy states and the intimidatory use of WTO trade agreements raise further concerns regarding the long term prospects of the FCTC. Disquiet at the role of the USA and UK in aggressively promoting the interests of TTCs and undermining health in developing countries led to revised instructions for their embassies intended to prevent its recurrence. ${ }^{131} 132$ Yet concerns about the adequacy of such guidelines ${ }^{133}$ have been heightened in the USA by accounts of their frequent infringement, ${ }^{134-138}$ while in the UK the quiet death of the DTI's investigation into BAT's involvement in smuggling ${ }^{139}$ raises questions about governmental commitment to effective oversight of corporate conduct overseas. ${ }^{56}$

More fundamentally, though the WTO agreements do offer some scope to protect public health, ${ }^{10}{ }^{140}$ these documents provide extensive evidence of how TTCs have used the threat of a WTO challenge as a stick to deter the adoption of effective legislation. ${ }^{12}$ There remains a strong case for more effectively protecting tobacco control from the threats posed by trade liberalisation. ${ }^{141}$ Arguably more pressing, however, is the need for greater understanding of WTO, regional and bilateral trade agreements among health officials and advocates, particularly in developing countries. The acquisition and dissemination of such expertise is a priority for global tobacco control.

\section{ACKNOWLEDGEMENTS}

This work was supported by the Rockefeller Foundation's Trading Tobacco for Health initiative, NIH grant R01 CA091021-03: "Globalization, the Tobacco Industry and Policy Influence" and NIH grants R01 CA90791: “Tobacco Industry Documents on ETSThe Next Front".

Documents cited in this paper not currently available on existing websites will be posted on the Tobacco Control Research page on the London School of Hygiene and Tropical Medicine website http:// www.lshtm.ac.uk/cgch/tobacco/index.html.

\section{Authors' affiliations}

R MacKenzie, J Collin, Centre on Global Change and Health, London School of Hygiene and Tropical Medicine, London, UK

K Sriwongcharoen, Action on Smoking and Health (ASH) Thailand M E Muggli, Nicotine Research Program, Mayo Clinic, Rochester, Minnesota, USA

\section{REFERENCES}

1 Vateesatokit $P$, Hughes B, Ritthiphakdee B. Thailand: winning battles, but the war's far from over. Tobacco Control 2000;9:122-7.

2 Chantornvong S, McCargo D. Political economy of tobacco control in Thailand. Tobacco Control 2001;10:48-54

3 Vateesatokit P. Tobacco control in Thailand. Mahidol Journal 1997;4(2):73-82.

4 SEARO. Press release: WHO commends Thailand's path breaking antitobacco efforts - cautions against any let up. New Delhi, SEARO SEA/PR/ 
1308 http://w3.whosea.org/prsrles/seapr1308.htm [Accessed 2 Jul 2004].

5 GATT. Thailand-Restrictions on Importation of and Internal Taxes on Cigarettes: Report of the Panel adopted on 7 November 1990 (DS10/ R-37S/200). http://www.worldtradelaw.net/reports/gattpanels/ thaicigarettes.pdf [Accessed 2 Jul 2004].

6 Chaloupka F, Laixuthai A. U.S. trade policy and cigarette smoking in Asia NBER Working Paper 5543. Cambridge, Massachusetts: National Bureau of Economic Research, 1996.

7 Chitanondh H. Defeat in trade-victory in health. Bangkok: Thailand Health Promotion Institute, 2001

8 Taylor A, Chaloupka FJ, Guidon E, et al. The impact of trade liberalization on tobacco consumption. In: Jha P, Chaloupka FJ, eds. Tobacco control in developing countries. Oxford: Oxford University Press, 2000:343-64.

9 Vateesatokit P. Tailoring tobacco control efforts to the country: the example of Thailand. In: de Beyer J, Waverley Brigden L, eds. Tobacco control policy: strategies, successes and setbacks. Washington DC: World Bank, 2003:154-79.

10 Bettcher D, Shapiro I. Tobacco control in an era of trade liberalisation. Tobacco Control 2001;10:65-7.

11 Thailand. Tobacco Products Control Act, B.E. 2535 (1992). (29 March 1992). http://www.thpinhf.org/T_Products_Control_Act-text.html [Accessed 27 Jun 2004].

12 Callard C, Chitanondh, Weissman R. Debate: Why trade and investment liberalisation may threaten effective tobacco control efforts. Tobacco Control 2001:10:68-70.

13 Chitanondh H. The passage of tobacco control laws. Bangkok: Thailand Health Promotion Institute, 2000

14 Chapman S. "Keep a low profile": pesticide residue, additives, and freon use in Australian tobacco manufacturing. Tobacco Control 2003;12(suppl III):iii45-53.

15 Wayne GF, Connolly G. How cigarette design can affect youth initiation into smoking: Camel cigarettes 1983-93. Tobacco Control 2002;11 (suppl I):i32-9.

16 Bates C, McNeil Al, Jarvis M, et al. The future of tobacco product regulation and labelling in Europe: implications for the forthcoming European Union directive. Tobacco Control 1999:8:225-35.

17 Pollay RW, Dewhirst T. The dark side of marketing seemingly "Light" cigarettes: successful images and failed fact. Tobacco Control 2002;11(supple I):i1 8-31.

18 Connolly G, Wayne GD, Lymperis D, et al. How cigarette additives are used to mask environmental tobacco smoke. Tobacco Control 2000;9:283-91.

19 MacKenzie R, Collin J, Lee K. The tobacco industry documents: an introductory handbook and resource guide for researchers. London: London School of Hygiene \& Tropical Medicine, 2003. http://www.lshtm.ac.uk/ cgch/tobacco/Handbook\%2008.07.03.pdf [Accessed 5 July 2004].

20 Bero L. Implications of the tobacco industry documents for public health and policy. Ann Rev Public Health 2003;24:267-88.

21 Balbach E. Tobacco industry documents: comparing the Minnesota Depository and internet access. Tobacco Control 2002;11:68-72.

22 Malone RE, Ballbach ED. Tobacco industry documents: treasure trove or quagmire? Tobacco Control 2000;9:334-8.

23 Collin J, Lee K, Gilmore AB. Unlocking the corporate documents of British American Tobacco: an invaluable global resource needs radically improved access. Lancet 2004:363:1746-7.

24 Muggli ME, LeGresley EM, Hurt RD. Big tobacco is watching: British American Tobacco's surveillance and information concealment at the Guildford depository. Lancet 2004;363:1812-19.

25 Lee K, Gilmore AB, Collin J. Looking inside the tobacco industry: revealing insights from the Guildford Depository. Addiction 2004;99:394.

26 Harris D. [PMAI Letter to Matt Winokur]. 14 Feb 1992. Philip Morris Bates No. 2023247376/7378. hitp://legacy.library.ucsf.edu/cgi/ getdoc?tid $=$ sbf78e00\&fmt $=$ pdf\&ref $=$ results.

27 BAT. [Industry Letter to Meechai Ruchuphan, Deputy Prime Minister]. 22 Oct 1991. British American Tobacco. Bates No. 304033997. Available from Guildford Depository.

28 Rudge L. Industry claimed to add sheep dip and rat poison to cigarettes. 12 Apr 1994. British American Tobacco. Bates No. 503092171/2172. Available from Guildford Depository.

29 Proctor C. Disclosure of ingredients information in Australia. 30 Mar 1994 British American Tobacco Bates No. 500876700. Available from Guildford Depository.

30 Boyse S. Ingredients/ASH Press Release. 13 Apr 1994. British American Tobacco. Bates No. 503062434/2435. Available from Guildford Depository.

31 Bishop D. British American Tobacco: Tobacco Future Business Environment. SECRET. British American Tobacco. Bates No. 800168845/8913. Available From Guildford Depository.

32 Mitchell TG. Additives and Cigarette Smoke Constituents. 2 Apr 1991. British American Tobacco. Bates No. 300560522 . Available from Guildford Depository.

33 BAT. TSG Note: Additives Issues. nd; probably 1994. Bates No. 503092094. Available from Guildford Depository.

34 Read GA. TSG Briefing Paper: Additives Register 26 Aug 1994. British American Tobacco. Bates No. 503105368. Available from Guildford Depository.

35 Busai S. Disclosure of cigarefte ingredients: potential domino effect? [editorial] Southeast Asian Journal of Tropical Medicine and Public Health 1994;25:613-615.

36 Trairatanobhas V. Government Lobbying. 13 Jan 1991. British American Tobacco. Bates No. 500046134. Available from Guildford Depository.
37 Marcotullio RJ. Thailand-Ingredient Disclosure. 14 Jan 1992. RJ Reynolds. Bates No. 509687277. http://legacy.library.ucsf.edu/cgi/ getdoc?tid $=$ pga73d00\&fmt $=$ pdf\&ref $=$ results

38 Moreno FJ. [PM Telex Urgent and Confidential from FJ Moreno to Don Harris] 3 Dec 1991. Philip Morris. Bates No. 2023247396. http:// legacy.library.ucsf.edu/cgi/getdoc?tid $=$ evu34e00\&fmt $=$ pdf\&ref $=$ results.

39 Foreman D. Thailand/Ingredient Disclosure. 14 May 1993. RJ Reynolds. Bates No. 508879523. http://legacy.library.ucsf.edu/cgi/ getdoc?tid $=$ wql30d00\& $\mathrm{fmt}=$ pdf\&ref $=$ results.

40 Leung A. Thailand Ingredient Regulation. 3 Jul 1995. Bates No. 800162141 British American Tobacco. Available from Minnesota Depository.

41 Aitken D. Re: PM Lobbying Efforts. 12 Mar 1992. British American Tobacco. Bates No. 304033891 . Available from Guildford Depository.

42 Andrade A. Update on Active Jurisdictions Concerning Ingredients issues. 2 Oct 1993. Philip Morris. Bates No. 2048794672/4675. http:// legacy.library.ucsf.edu/cgi/getdoc?tid = kvu22a00\&fmt $=$ pdf\&ref $=$ results.

43 Harris D. [PMAI Fax to Matt Winokur] 28 Jun 1991. Philip Morris. Bates No. 2500053249/3255. http://legacy.library.ucsf.edu/cgi/ getdoc?tid $=$ ugi $19 \mathrm{e} 00 \& \mathrm{fmt}=\mathrm{pdf} \& \mathrm{ref}=$ results

44 Tobacco products Control Act BR. [Fax from Baker \& McKenzie] 19 Jun 1991. Bates No. 2500053251/3255. http://legacy.library.ucsf.edu/cgi/ getdoc? tid $=$ hif $42 \mathrm{e} 00 \& \mathrm{fmt}=$ pdf\&ref $=$ results

45 Andrade T. Update on Thailand Ingredients Meeting. 3 Dec 1996. British American Tobacco. Bates No. 700861275/1280. Available from Minnesota Depository.

46 Aitken D. Re: Draft Tobacco Control Bill. 28 Feb 1992. British American Tobacco. Bates No. 304033949. Available from Guildford Depository.

47 Harris D. [PMAl Inter-Office Correspondence to Francisco J Moreno] 3 Dec 1991. Philip Morris. Bates No. 2504025109/5111. http:// legacy. library. ucsf.edu/cgi/getdoc?tid $=$ bsq $19 \mathrm{e} 00 \& \mathrm{fmt}=$ pdf\&ref $=$ results.

48 Aitken D. Re: Ingredients Disclosure. 13 Feb 1992. British American Tobacco. Bates No. 304034013. Available from Guildford Depository.

49 Trairatanobhas V. [BAT Lefter to Richard Davies]. 27 Feb 1992. British American Tobacco. Bates No. 304033954. Available from Guildford Depository.

50 Trairatanobhas V. [BAT Letter to Richard Davies]. 27 Feb 1992. British American Tobacco. Bates No. 304033955. Available from Guildford Depository.

51 WHO. Tobacco Industry Strategies to Undermine Tobacco Control Activities at the World Health Organization. August 2000. http://www. who.int/ tobacco/media/en/who_inquiry.pdf [Accessed 2 Jul 2004].

52 Dietrich P. Thai Ingredient Labeling Regulations. 6 Mar 1992. British American Tobacco. Bates No. 304033907/3309. Available from Guildford Depository.

53 Aitken D. Re: Draft Tobacco Control Bill/Non Smokers Protection Act. 9 Mar 1992. British American Tobacco. Bates No. 304033903/3905. Available from Guildford Depository.

54 Aitken D. Re: Dietrich Fax. 10 Mar 1992. British American Tobacco. Bates No. 304033895. Available from Guildford Depository.

55 Trairatanobhas V. Industry Meeting with Deputy Prime Minister Meechai Rachuphan at Government House British American Tobacco. 30 Sep 1991 British American Tobacco. Bates No. 5025757203/7207. Available from Guildford Depository.

56 Collin J, LeGresley E, MacKenzie R, et al. Complicity in contraband: British American Tobacco and cigarette smuggling in Asia. Tobacco Control 2004;13(Suppl II):ii104-11

57 Trairatanobhas V. [BAT FAX to Richard Davies. 22 Oct 1991. British American Tobacco. Bates No. 301135704 . Available from Guildford Depository.

58 Davis R. Developments in Thailand. 10 Mar 1992. British American Tobacco. Bates No. 304033896. Available from Guildford Depository.

59 Philip Morris. Asia/Pacific Three Year Plan 1992-1994. 11 Dec 1991. Philip Morris. Bates No. 2500064000/4226. http:// legacy.library.ucsf.edu $/ \mathrm{cgi} /$ getdoc?tid $=$ wwil $9 \mathrm{e} 00 \& \mathrm{fmt}=$ pdf\&ref $=$ results.

60 Aitken D. [BAT Letter to Amanda Walker]. 22 Jan 1992. British American Tobacco. 304034077/4082. Available from Guildford Depository.

61 Harris D. [PMAI Inter-office Correspondence to William H Webb]. Philip Morris. 25 Oct 1991. Bates No. 2504025129/5135. http:// legacy.library. .ucsf.edu $/ \mathrm{cgi} /$ getdoc?tid $=$ vrq 19e00\&fmt $=$ pdf\&ref $=$ results.

62 Mitchell TG. Additives and Cigarette Smoke Constituents. 2 Apr 1991 British American Tobacco. Bates No. 300560522 . Available from Guildford Depository.

63 Aitken D. [BAT Letter to Amanda Walker] 22 Jan 1992. British American Tobacco. Bates No. 304034077/4081. Available from Guildford Depository.

64 Davies R. Tobacco Product Control Bill-Thailand. 14 January 1992. British American Tobacco. Bates No. 502575693. Available from Guildford Depository.

65 Thailand. Secretariat of the Cabinet. History of the Cabinet. http:// www.cabinet.thaigov.go.th/eng/bb_main 1 1.htm [Accessed 28 Jun 2004]

66 Davies R. Thailand. 23 Jun 1992. British American Tobacco. Bates No. 304033759. Available from Guildford Depository.

67 Aitken D. Thailand Tobacco Act. 22 Jul 1992. British American Tobacco. Bates No. 502575650/5652. Available from Guildford Depository.

68 Aitken D. Re: Meeting with Minister of Health 21 Aug 1992. British American Tobacco. Bates No. 400920624/0631. Available from Guildford Depository.

69 Aitken D. Re: Minutes of Meeting With MOH. 1 June 1992. British American Tobacco. Bates No. 304033790/3793. Available from Guildford Depository. 
70 Trairatanobhas. Re: Industry Meeting. 23 Feb 1993. British American Tobacco. Bates No. 304033687/3688. http://tobaccodocuments.org/ guildford_misc/304033684-3701.html [Accessed 3 Jul 2004].

71 Aitken D. New Minister of Health Appointed/Industry Meeting. 21 Apr 1992. British American Tobacco. Bates No. 304033824/3826. Available from Guildford Depository.

72 Riordan M. 'By Brand' Ingredients for Thailand. [BAT e-mail forwarded by Orm Porntipprapa to distribution]. 27 Mar 1998. Bates No. 321112039 ) 2040. Available from Minnesota Depository.

73 Aitken D. Re: Meeting with MOH and Subsequent industry Meeting. 31 Aug 1992. British American Tobacco. 400920604/0609. Available from Guildford Depository

74 Smith OC. Thailand-ingredients Disclosure. 28 Aug 1992. PM. Bates No. 2050763882/3883. http://legacy.library.ucsf.edu/cgi/ getdoc?tid $=$ qtq09e00\&fmt $=$ pdf\&ref $=$ results.

75 Foreman D. Thailand ingredient Disclosure. 28 Aug 1992. RJ Reynolds. Bates No. 508879531. http://legacy.library.ucsf.edu/cgi/ getdoc?tid $=$ zql30d00\&fmt $=$ pdf\&ref $=$ results

76 Boyse S. Ingredients. 15 Apr 1994. British American Tobacco. Bates No. 503872506/2508. Available from Guildford Depository

77 Rajiv Goel [BAT letter to Brendan Brady]. 31 Mar 1994. British American Tobacco. Bates No. 502592958/2959. Available from Guildford Depository.

78 Rekart P. Ingredients. 23 Dec 1994. Philip Morris. Bates No. 2076407639 http://legacy.library.ucsf.edu/cgi/getdoc?tid = adj85c00\&fmt = pdf\&ref= results.

79 Riordan M. [Letter to Thailand Minister of Public Health]. 20 Feb 1998. British American Tobacco. Bates No. 2064814430/4431. http:// legacy.library.ucsf.edu/cgi/getdoc?tid =ija87d00\&fmt = pdf\&ref $=$ results

80 Riordan M. [BAT Memorandum to Industry Personnel] 17 Feb 1998. British American Tobacco. Bates No. 519426984/6986. http:// legacy. library.ucsf.edu/cgi/getdoc?tid $=$ ztd30d00\&fmt $=$ pdf\&ref $=$ results.

81 Leung A. Thailand Ingredient Issue-Product Redevelopment. 21 July 1995. British American Tobacco. Bates No. 500241365/1366. Available from Guildford Depository.

82 Kemball B. Thailand Ingredients. 20 Sep 1995. British American Tobacco. Bates No. 500241355/1356. Available from Guildford Depository.

83 Aitken D. Meeting with Minister of Health. 21 Aug 1992. British American Tobacco. Bates No. 4009206240630. Available from Guildford Depository.

84 Webb W. Thailand: Marlboro Ingredients Modification. 7 Jun 1995. Philip Morris. Bates No. 2050890222. http://legacy.library.ucsf.edu/cgi/ getdoc?tid $=1 \mathrm{bm} 80 \mathrm{c} 00 \& \mathrm{fmt}=$ pdf\&ref $=$ results.

85 Harris D. [PM Telex to Distribution]. 18 Sep 1996. Philip Morris. Bates No. 2063618170/8173. http://legacy.library.ucsf.edu/cgi/ getdoc?tid $=$ akq22d00\& fmt $=$ pdf\& ref $=$ results .

86 Kemball B. Email: Thailand Ingredient Issue-Product redevelopment. 21 July 1995. British American Tobacco. Bates No. 500241373. Available from Guildford Depository.

87 Kemball B. Notes on Meeting on Thailand Ingredients Issues. 19 Sep 1995 British American Tobacco. Bates No. 500241352/1354. Available from Guildford Depository.

88 Taveevirat K. Re: Thai Ingredient Law . 10 Aug 1999. Bates No. 321780997. Available from Minnesota Depository.

89 Coddington K. [Fax Re: Final Thailand Confidentiality Agreement] 21 Nov 1997. British American Tobacco. Bates No. 321780785. Minnesota Tobacco Document Depository.

90 Thailand Confidentiality Agreement. [Agreed to by British American Tobacco Co. Ltd., Brown \& Williamson Tobacco Corp., Japan Tobacco Inc., Philip Morris Companies, Inc., R.J. Reynolds Tobacco Co., Rothmans International Services Ltd., Reemtsma GmbH \& Co, and House of Prince]. 21 Nov 1997. British American Tobacco. Bates No. 321780786/80793. Available from Minnesota Depository.

91 Webb W. Thailand: Marlboro Ingredient Modification. 9 June 1995. Philip Morris. Bates No. 2047343196E/3196F. http://legacy.library.ucsf.edu/ $\mathrm{cgi} /$ getdoc?tid $=$ hog $26 \mathrm{c00 \& fmt}=$ pdf\&ref $=$ results .

92 Geubels P. [E-mail Re: Thai Ingredient Law]. 11 Aug 1999. British American Tobacco. Bates No. 321780999/1000. Available from Minnesota Depository.

93 Godby P. [E-mail Re: Thai Ingredient Law] 13 Aug 1999. British American Tobacco. Bates No. 321780987/0989. Available from Minnesota Depository.

94 Cunningham R. Smoke and mirrors: the Canadian tobacco war. Ottawa: International Development Research Centre, 1996

95 Frankel G. Thailand Resists U.S. Brand Assault, Washington Post, 18 Nov 1996 http://www.washingtonpost.com/wp-svv/national/longterm/ tobacco/stories/global2.htm [Accessed 6 Jul 2004].

96 Embassies of Great Britain, Japan and the United States. [letter to Varabhorn Bhumiswadi, Director Institute for Tobacco Consumption Control. 20 Apr 1995. RJR Bates No. 521422361/2362. http://

legacy.library.ucsf.edu/cgi/getdoc?tid = jqo51 c00\&fmt $=$ pdf\&ref $=$ results

97 Harris D. [PM Letter to Distribution]. 14 Oct 1996. Philip Morris. Bates No. 2064814622/4623. http://legacy.library.ucsf.edu/cgi/ getdoc?tid $=$ vqo94c00\& $f m t=$ pdf\&ref $=$ results

98 Kumaranayake L, Lake S. Regulation in the context of global health markets. In: Lee K, Buse K, Fustukian S, eds. Health policy in a globalising world. Cambridge: Cambridge University Press, 2002:78-96.

99 Aitken D. [BAT Letter to Richard Davies] 2 Mar 1992. British American Tobacco. Bates No. 304033943. Available from Guildford Depository.

100 Davies R. [BAT Letter to David Aitken, Bangkok]. 6 Apr 1992. British American Tobacco. Bates No. 304033850. Available from Guildford Depository.
101 Davies R. Minutes of Industry Meeting on April 9 1992, 3:30 pm at RJR Office 15 Apr 1992. British American Tobacco. Bates 30403384438/3845. Available from Guildford Depository.

102 Trairatanobhas V. Minutes of Industry Meeting at PMI Office June 221992. 23 Jun 1992. British American Tobacco. Bates No. 3040337613763. Available from Guildford Depository.

103 Lambertson D. Letter to His Excellency Boonpun Kaevatana, Minister of Public Health. 8 Sep 1993. British American Tobacco. Bates No. 503872513/2514. Available from Guildford Depository.

104 Brady B. Thailand. 14 Apr 1994. British American Tobacco. Bates No.503872511/2514. Available from Guildford Depository.

105 von Kotze JA. Ingredients Issue. 8 Mar 1994. British American Tobacco (Rothmans). Bates No. 500900404. Available from Guildford Depository.

106 Goel R. Re: Ingredient Issue. 8 Mar 1994. British American Tobacco. Bates No. 500900412/0413. Available from Guildford Depository.

107 Virochpoka P. Ingredients Issue. 30 Mar 1995. British American Tobacco. Bates No. 500900360. Available from Guildford Depository.

108 Brady B. Thailand/Ingredients. 31 Mar 1992. British American Tobacco. Bates No. 500900358. Available from Guildford Depository.

109 Leung A. [Correspondence sent to Chris Proctor, BAT Staines]. 3 Apr 1995. British American Tobacco. Bates No. 5009003470357. Available from Guildford Depository.

110 Trairatanobhas V. Tobacco Control Bill. 30 Jan 1992. British American Tobacco. Bates No. 304034034/4036. Available from Guildford Depository.

111 Davies R. [BAT Fax to Paul Dietrich]. 28 Feb 1992. British American Tobacco. Bates No. 502575679/5687. Available from Guildford Depository.

112 Brendan B. Thailand-Ingredients. 26 Jan 1995. British American Tobacco. Bates No.700171490/1495. Available from Minnesota Depository.

113 Brady B. Thailand/Tobacco Ingredients Disclosure. 27 Jan 1995. Bates No. 5009003370338 . Available from Guildford Depository

114 Brown D. Thailand: Cigarette Ingredients Disclosure. 5 Apr 1995. British American Tobacco. Bates No. 500900343. Available from Guildford Depository.

115 Brown D. Thailand: Cigarette Ingredients Disclosure. 28 Mar 1995. British American Tobacco. Bates No. 500900340/0341. Available from Guildford Depository.

116 Bramley B. [BAT Letter to Prime Minister Chuan Leekpai] 31 May 1995 British American Tobacco. Bates No. 502575534/5544. Available from Guildford Depository.

117 A Critical Analysis of the Ministerial Regulations to be Issued Pursuant to Section 11 of the Tobacco Products Control Act 1992, as acknowledged by the Council of Ministers on 16 May 1995. 31 May 1995. British American Tobacco. Guildford Depository. Bates No. 502575535/5544. Available from Guildford Depository.

118 Leung A. Ingredients Disclosure. 24 May 1995. British American Tobacco. Bates No. 500900317. Available from Guildford Depository.

119 Philip Morris Asia. Industry Meeting on Thailand Ingredients' Disclosure. 17 Sep 1996. Philip Morris. Bates No. 2073419095/9097 http:// legacy.library. ucsf.edu/cgi/getdoc?tid $=f l q 42 \mathrm{c00} \& \mathrm{fmt}=\mathrm{pdf} \& \mathrm{ref}=$ results

120 Riordan M. [BAT letter to SL Rolston, Second Secretary, Embassy of the United States, Bangkok]. 5 Feb 1998 . British American Tobacco. Bates No. 2064814475/4477. http://legacy.library.ucsf.edu/cgi/ getdoc?tid $=$ ejo94c00\&fmt $=$ pdf\&ref $=$ results .

121 Windholz E. Thailand Ingredients. 25 Nov 1996. Philip Morris. Bates No. 2065340819/0822. http://legacy.library.ucsf.edu/cgi/ getdoc?tid $=$ lys63c00\&fmt $=$ pdf\&ref $=$ results

122 Riordan M. Thai Ingredients Suspension. 6 Feb 1998. British American Tobacco. Bates No. 2065340469/0470. http://legacy.library.ucsf.edu/ cgi/getdoc?tid $=$ gss63c00\&fmt $=$ pdf\&ref $=$ results

123 Godby P. [E-mail correspondence, Subject: Thai Ingredient Law]. 13 Aug 1999. British American Tobacco. Minnesota Tobacco Document Depository. Bates No. 321780987/0989.

124 Tobacco Consumption Control Institution, Ministry of Public Health, Thai Public Health Research Institution, Public Health System Research Institution. Academic Information- Disclosure of Cigarette Ingredients under Section 11 of the Tobacco Products Control Act B.E. 2535. May 1996. Philip Morris. Bates No. 2063618140/8167 http://legacy.library.ucsf.edu/cgi/ getdoc?tid $=$ znj67e00\&fmt $=$ pdf\&ref $=$ results

125 Friedman MP. Thailand Ingredient Disclosure Regulation. 22 May 1998. Philip Morris. Bates No. 2076254488/4492. http:// legacy. library.ucsf.edu/cgi/getdoc?tid $=$ iny $45000 \& f m t=p d f \& r e f=$ results.

126 Philip Morris International. Cigarette ingredients: What's in Philip Morris brands sold in Thailand. PMI website http://www. philipmorrisinternational.com/pages/eng/smoking/Ingredients_th.asp [Accessed 3 Jul 2004].

127 British American Tobacco. Social Report 2003/04: Responsible Product Stewardship. BAT website http://www.bat.com/oneweb/sites/ uk_3mnfen.nsf/rwPagesWebLive/DO5Z5AUR/ [Accessed 3 Jul 2004].

128 Parsons W. Public policy: An introduction to the theory and practice of policy analysis. Cheltenham: Edward Elgar, 1995.

129 World Health Organization. Framework Convention on Tobacco Control. 21 May 2003. http://www.who.int/tobacco/areas/framework/final_text/ en/ [Accessed 6 Jul 2004]

130 Hammond R, Assunta M. The Framework Convention on Tobacco Control: promising start, uncertain future. Tobacco Control 2004;12:241-2.

131 Mackay J. International Aspects of US Government Tobacco Bills. JAMA 1999;281:1849-50.

132 BBC News. Foreign Office Ban on Tobacco Events. 18 May 1999 http:// news.bbc.co.uk/1/hi/health/347120.stm [Accessed 6 Jul 2004]. 
133 Weissman R, Hammond R. International Tobacco Sales. Foreign Policy in Focus (Rev. 2000; 3(17). Washington DC, Institute for Policy Studies http:// www.foreignpolicy-infocus.org/briefs/vol3/v3n17tob.html [Accessed 6 Jul 2004].

134 Kaufman M. GAO: USDA Agency Breaks Rules Against Tobacco Aid. Washington Post; Wednesday 2 July 2003: Page A21. http:// www.washingtonpost.com/ac2/wp-dyn/A603212003Jul 1 ? language $=$ printer [Accessed 6 Jul 2004]

135 Kaufman M. U.S. Helps Tobacco in Trade Case South Korea Alters Rules. Washington Post, Tuesday 26 June 2001. http://lists.essential.org/ pipermail/intl-tobacco/2001q2/000524.html [Accessed 6 Jul 2004].

136 Waxman H, Durbin RJ. Letter to President Bush. 12 Feb 2003. http:// www.house.gov/reform/min/pdfs/pdf_inves/pdf_tobacco_bush_ admin_feb_12_let.pdf [Accessed 6 Jul 2004].

137 Waxman $\mathbf{H}$, Durbin J, Doggett L. Letter to President Bush. 26 Feb 2003. http://www.house.gov/reform/min/pdfs/pdf_inves/ pdf_tobacco_bush_admin_feb_26_let.pdf [Accessed 6 Jul 2004].

138 United States General Accounting Office. GAO-03-618. Tobacco Exports: USDA's Foreign Agricultural Service Lacks Specific Guidance fro Congressional Restrictions on promoting Tobacco, May 2003. http:// www.house.gov/reform/min/pdfs_108/pdf_inves/
pdf_tobacco_gao_FAS_rep.pdf [Accessed 6 Jul 2004]

139 Department of Trade and Industry. Press Release-British American Tobacco. P/2004/118. 26 March 2004 http://www.gnn.gov.uk/environment/ detailasp?ReleaselD = $112695 \&$ NewsAreaID = 2\&NavigatedFrom Department [Accessed 24 Jun 2004].

140 WHO/WTO. WTO Agreements and public health: a joint study by the WHO and the WTO Secretariat. 2002. Geneva: WHO/WTO. http://www. who.int/media/homepage/en/who_wto_e.pdf [Accessed 1 Jul 2004].

141 Shapiro I. Treating cigarettes as an exception to the trade rules. SAIS Review 2002;22:87-96. 